\title{
Kernos
}

Revue internationale et pluridisciplinaire de religion grecque antique

$34 \mid 2021$

Varia

\section{The Akragas Dialogue. New Investigations on Sanctuaries in Sicily}

Nicola Cucuzza

\section{(2) OpenEdition \\ Journals}

Electronic version

URL: https://journals.openedition.org/kernos/3938

DOI: 10.4000/kernos.3938

ISSN: 2034-7871

\section{Publisher}

Centre international d'étude de la religion grecque antique

\section{Printed version}

Date of publication: 31 December 2021

Number of pages: 297-299

ISBN: 978-2-87562-305-8

ISSN: 0776-3824

\section{Electronic reference}

Nicola Cucuzza, "The Akragas Dialogue. New Investigations on Sanctuaries in Sicily", Kernos [Online], 34 | 2021, Online since 31 December 2021, connection on 15 March 2023. URL: http:// journals.openedition.org/kernos/3938 ; DOI: https://doi.org/10.4000/kernos.3938

This text was automatically generated on 15 March 2023.

All rights reserved 


\title{
The Akragas Dialogue. New Investigations on Sanctuaries in Sicily
}

\author{
Nicola Cucuzza
}

\section{REFERENCES}

Monica DE CESARE, Elisa Ch. PORTALE, Natascha SOJC (eds.), The Akragas Dialogue. New

Investigations on Sanctuaries in Sicily, Berlin, De Gruyter, 2020.1 vol. $17 \times 24 \mathrm{~cm}$, VIII + 422 p. ISBN : 978-3-11-05027-1.

1 A study of the sanctuaries in ancient Sicily cannot ignore the knowledge of Akragas, whose extraordinary Valley of the temples is one of the most evocative archaeological sites in the Greek world. The evidence offered by some sanctuaries of this important polis is analyzed in this volume, which collects the contributions presented in a conference held in 2016 as the result of a synergy between the Universities of Palermo and Augsburg. As rightly pointed out in the Introduction by the curators of the volume, the monumentality of the temples of Akragas led to greater attention on the architectural datum with respect to the cultual practices to which they were intended. The Introduction, which illustrates the genesis of the work, indicates how the focus of the volume is therefore on the latter, framing the data relating to Akragas in a broader panorama, thanks also to the comparison with other sanctuaries in ancient Sicily, subject of recent surveys and studies.

2 The nineteen papers collected in the volume can be divided into three different parts: the first one is a general introduction, relating to the theme of ritual practice. J. Wallensten takes into consideration the theme of the relationship between dedicator and divinity, in the light of the sculptural dedications in the sanctuaries and onomastics. I. Patera devotes her attention to the problem of identifying the divinity object of worship on the basis of the archaeological data alone; in Sicily, many 
sanctuaries are nowadays identified as places of worship to Demeter, especially on the basis of the evidence offered by the discovery of terracotta statuettes. The scholar's analysis calls for greater caution: in fact, attention should be paid to the local variability of the manifestations of the cult and to the recurrence of identical votives in sanctuaries where-on the basis of literary or epigraphic sources-different divinities were worshipped. A. Pautasso focuses her attention on the diffusion of figurines bearing objects (cakes, focaccia, probably wool), found at the end of the fifth and at the beginning of the fourth century $\mathrm{BC}$; they could be related to the hegemonic role then exercised on the island by Syracuse.

3 The second part of the volume is specifically dedicated to Akragas. M.C. Parello presents a history of the archaeological research at the site, from travelers in the eighteenth century to today: the main interest has long been catalyzed by the monumental Doric temples, which are still the main attraction for visitors to the archaeological site. It is only with the archaeological research carried out since the 1930s by P. Marconi that investigations have been devoted to areas which, although characterized by less monumentality, are of great interest to infer more data about the cultic practices at Akragas. It would be very interesting in the next future to pay more attention on the development of the different approaches that archaeological research has known in Akragas, framing them in a broader context.

4 The other papers dedicated to Akragas concern the research carried out both in the area of the Valley of the Temples and in the area closest to the modern town of Agrigento: in some cases these are investigations by young scholars, still in progress.

5 E.Ch. Portale and M. De Cesare, in a very interesting study, clarify chronology and functions of the architectural structures located between the southern front of the Temple of Zeus and the city walls. In particular, the Shrine south of the Olympieion shows two architectural phases, dating to the Archaic period and the beginning of the fifth century BC: in both of them inside the building there was a rectangular pit which was characterized by the deposition of numerous objects (especially bronze phialai). The architectural structures located further south are referred to the ritual activities that took place in the Shrine. The so-called Edificio a cameroni is believed to be a large hall for the theoxenic banquet. Due to the architectural data and the findings (also including clay figurines and deer bones), Portale and de Cesare suggest that the entire complex was intended for female rites of passage, with a cult paid to Artemis, but with a sharing of rites with the Dioscuri and Helen, also in accordance with the literary documentation relating to Akragas.

6 A careful architectural study is dedicated by M. Longo to the temple with a tripartite plan, built in the sixth century BC east of Porta $V$. A. Rheeder presents an interesting investigation on the fragments of archaic terracotta roofs, found in various locations between the Temple of Zeus and Porta IV: they belong to the same building, the exact identification of which remains however undetermined at the moment. F. Ducati refers on the architectural data of a couple of buildings (perhaps for religious functions) unearthed in the 1920s near the town of Agrigento and neglected by subsequent archaeological research. C. Genovese re-examines the data relating to the sanctuary near the church of San Biagio, divided into two terraces placed at different heights; in the upper sanctuary there are two moments of use (of the fifth and fourth centuries $\mathrm{BC})$. While the traditional identification with Demeter of the divinity venerated on the 
upper terrace is accepted, Genovese agrees with the distinction from the Santuario rupestre, located slightly lower, which probably housed a cult to the Nymphs.

7 A. Serra turns her attention to the theme of offerings in the sanctuaries, providing preliminary information on a study on the bronze artefacts retrieved in the Akragas' sanctuaries. The topic of the offerings is discussed more fully by N.Sojc, who summarizes the results of the research carried out since 2013 in the extra-urban sanctuary near the church of Sant'Anna. Due to the new excavations, fresh data are now available on the depositional practice of ceramic vessels, clay figurines, metal objects and animal bones. Sojc suggests a distinction between "single-act deposits" and "prompting depositions". The former consists of groups of materials deposited together with organic material in a single moment; on the basis of the location of the objects a ritual action is distinguished in the "prompting depositions"; it included a libation carried out through a broken vase fixed to the ground, and the subsequent accurate placement of whole vessels, bones animals and remains of meal to cover it up. R. Miccichè presents a preliminary information on the faunal remains found in the excavations carried out in the sanctuary of Sant'Anna, largely pertaining to young pigs.

The third section, relating to other sanctuaries in Greek Sicily, starts with an article by M. Albertocchi on the Thesmophorion of Bitalemi in Gela during the Archaic period: in addition to the method of deposition of the objects, attention is paid to the relationship between them and a small building in unfired bricks.

Three papers deal with Selinus: F. Spatafora and C. Greco provide fresh data on the cultic attendance of the sanctuaries of Malophoros and Zeus Meilichios. The two studies add new data on the deposition of pottery vases, metal objects and clay figurines, also due to a re-examination of the archaeological data retrieved in the old excavations carried out in the same area. C. Marconi summarizes the results of the research carried out in the area of Temples B and R on the acropolis, where the remains of two unfired brick constructions (dating back to the end of the seventh century $\mathrm{BC}$ ) were identified. Temple $\mathrm{R}$ is believed to be dedicated to the cult of Demeter due to the type of votives and the prevalence of pig bones among those of sacrificed animals. It is suggested the existence of a theatral area (capable of hosting 500 people) in front of the temple: it would indicate the carrying out of ceremonies which probably included dances.

10 Two papers (by E. Mango and M. Boglione) are devoted to the new excavations at Hymera: on the Piano del Tamburino two sacred areas have recently been retrieved, dating back to the sixth-fifth century BC. D. Leggio finally illustrates in a preliminary way the architectural complex of 25 rooms, dated to the third century BC, unearthed in Akrai between the theater and the Aphrodision and interpreted as a sanctuary of Demeter and Kore.

11 The main interest of the volume lies in the particular attention paid to the use of the archaeological data to reconstruct the ritual practice of sanctuaries. In particular, the seminal study by Portale and de Cesare on the area south of the Olympieion at Akragas indicates how much a careful investigation of all the available data can reveal, even on sanctuaries which have been known for a long time. This is a study perspective that would be interesting to apply to other important sites in Sicily, such as Syracuse. From an editorial point of view, the completely unusable Index is regrettable; moreover, an overall map of Akragas would be desirable, to allow readers who are not very familiar with the site's topography to locate the sanctuaries mentioned in the volume. It is hoped that other investigations may soon broaden the framework of knowledge on 
sanctuaries in Sicily, taking the periods subsequent to the sixth and fifth centuries BC (on which the attention of scholars has so far been mainly focused) into consideration as well.

\section{AUTHORS}

NICOLA CUCUZZA

Università di Genova 